\author{
M. Wesam Al Asali, Michael H. Ramage
}

\title{
Learning through building: Approaches to craft training in thin-tile vaulting
}

\author{
Aprender construyendo: Enfoques sobre la enseñanza \\ del oficio de las bóvedas tabicadas
}

Aprender através da construção: Abordagens à formação artesanal em abóbadas catalãs

Keywords $\mid$ Palabras clave $\mid$ Pallaviras chave

Tacit learning, Timbrel vaults, Traditional construction, Knowledge transfer, Mediterranean

Aprendizaje tácito, Bóvedas tabicadas, Construcción tradicional, Transferencia de conocimientos, Mediterráneo

Aprendizagem tácita, Abóbadas catalãs, Construção tradicional, Transferência de conhecimentos, Mediterrâneo

\begin{abstract}
Resumen | Resumo
Short-term training is becoming the dominant model of knowledge transfer in construction crafts. In the case of thintile vaulting, the historical master-apprentice training model is being partly replaced with experimental and projectspecific training programs, some of which introduce the techniques to new regions and cultures. Challenges of time, site conditions, and the adaptation of the technique to local construction become intrinsic to the learning process. To address these challenges, this article will examine two thin-tile vault training programs in Rwanda and Spain. An ethnographic study will draw on social learning theories to explore how training is connected to the social and economic context of each project. Lessons from these workshops will form a training strategy model for traditional construction crafts. Finally, the study will project these lessons onto the pedagogy of architecture and design.
\end{abstract}

La formación a corto plazo se está convirtiendo en el modelo predominante para la transferencia de conocimientos en los oficios de la construcción. En el caso de la bóveda tabicada, el modelo histórico de formación de maestro-aprendiz está siendo sustituido, en parte, por programas de formación experimentales centrados en proyectos específicos, algunos de los cuales introducen estas técnicas en nuevas regiones y culturas. Los retos impuestos por el tiempo, las condiciones del lugar y la adaptación de la técnica a la construcción local son consustanciales al proceso de aprendizaje. Para abordar estos problemas, en el artículo se examinan dos programas para enseñar a construir bóvedas tabicadas en Ruanda y España. Un estudio etnográfico se basará en las teorías sobre el aprendizaje social para explorar cómo se integra la enseñanza en el contexto socioeconómico de cada proyecto. Las lecciones aprendidas en estos talleres formarán un 
modelo de estrategia para la enseñanza de los oficios de la construcción tradicional. Por último, el estudio proyectará estas lecciones sobre la pedagogía de la arquitectura y el diseño.

A formação de curto prazo está a tornar-se o modelo dominante de transferência de conhecimentos nos ofícios da construção. No caso da abóbada catalã, o modelo histórico de formação de um mestre-aprendiz está a ser parcialmente substituído por programas de formação experimentais e específicos do projecto, alguns dos quais introduzem as técnicas em novas regiões e culturas. Os desafios de tempo, das condições do local, e a adaptação da técnica à construção local tornam-se intrínsecos ao processo de aprendizagem. Para fazer face a estes desafios, este artigo examinará dois programas de formação em abóbadas catalãs no Ruanda e em Espanha. Um estudo etnográfico basear-se-á em teorias de aprendizagem social para explorar a forma como a formação está ligada ao contexto social e económico de cada projecto. As lições retiradas destas oficinas formarão um modelo de estratégia de formação em ofícios tradicionais de construção. Finalmente, o estudo irá projectar estas lições sobre a pedagogia da arquitectura e do desenho.

\section{Introduction}

Thin-tile vaulting, also called Catalan, Timbrel, and Guastavino vaulting, is a Mediterranean ceiling-craft that relies on the horizontal positioning of lightweight tiles bonded with fast-setting mortar, hence needing little or no formwork (Collins 1968). As a building craft, it employs less material, but more skill, than reinforced concrete construction, thus learning the technique is crucial in building thin-tile vaults. In fact, the earliest document about thin-tile vaulting, a letter written by King Peter IV of Aragón in 1382, talks about sending builders and architects from Aragón to Valencia to "learn" the advantageous technique (Ochsendorf 2010).

Where thin-tile vaulting historically exists, it is a tradition and an identity that is practiced vernacularly and institutionally. In Spain, before industrialized construction was widespread, training in tile-vaulting took place in two different ways. The first was the traditional form of learning within families dedicated to this trade. The other form was within recognized schools of art, usually in three-year programs on designing, calculating, and building vaults (Musté and Nonell 1947: 3). Starting in the 1950s, when concrete construction eclipsed thin-tile vaulting, official polytechnic training of builders stopped and thin-tile vaults became limited to vernacular architecture and small circles of artisans working mainly on restoration projects.

Apart from the knowledge transmission passed down through generations of builders, another kind of transmission occurs when knowledge is exchanged between regions, in which case the location, not the time, is the context. At the beginning of the twentieth century, the Madrilenian architect and craft enthusiast Juan Bautista Lázaro brought thin-tile vault builders from Catalonia to the capital during the construction of his celebrated residential and religious projects (García-Gutiérrez Mosteiro 1996: 231-32). Their craft was sustained in Central Spain and contributed to the post-war reconstruction of the region between 1940 and 1960. Another exemplary transfer of the technique is the work of the Valencian engineer Rafael Guastavino and his son Guastavino Jr. during the first half of the twentieth century in North America. Although they worked on more than one thousand projects across the United States, no records on the administration of the company or the training of labor have been found to date, only photos showing Guastavisnos' builders on construction sites (Fig. 1).

In more recent examples, vernacular knowledge in Spain became a source of global thin-tile projects. In 2007, Spanish builders from Extremadura were recruited to work with masons from the United Kingdom to build the dome of the Pines Calyx center in Kent, the first thin-tile vaulted project in the United Kingdom and also the first one outside Spain in the twenty-first century (Ramage 2007). James Bellamy, from the United Kingdom team, became a trainer himself. He later had played an essential role on two thin-tile vaulted projects in Mapungubwe, in South Africa, and Kigali, in Rwanda; both are examples of low-cost and locally resourced constructions. Since then, the interest in training has been increasing with the escalating use of thintile vaulting as sustainable and site-aware construction. 
In Spain, training workshops, specifically for students of architecture, have been relatively common. Since 2010, schools of Architecture in Madrid, Valencia, Alcalá de Henares, and Barcelona have conducted short workshops within their architectural education curriculum (Fuentes and Huerta 2014; "VIII Taller de Bóvedas Tabicadas MUPAAC” 2020). More vocational-like summer schools have also offered one-week workshops, such as "Taller de Bóvedas" in Guadalajara, Escola Origens in Catalonia, and Homo Faber in León (Origens - Escola Taller de Bioconstrucció 2020; Homo Faber - Rehabilitación de Edificios y Cursos de Oficios 2020). The instructors of these workshops are professionals and master builders working mainly on restoration projects, as well as vaulted stair specialists.

Therefore, today's transfer of thin-tile vaulting is less about passing down and more about passing on. Short, concise training workshops are prevalent, in contrast to the master-apprentice model. This prompts the following questions: How can thin-tile vaulting, as an example of a construction craft, be situated in the construction industry? How can today's short and in-focus learning of thin-tile vaulting prepare builders for further autonomous thin-tile applications?

\section{Theoretical framework: Context and content}

Studying the history of thin-tile modes of learning reveals two different approaches, one that focuses on profession and technique, and one that focuses on design and analysis. The former is about a structure that needs to be built with supervision from the leading designer or master craftsperson; the latter entails understanding the geometrical, material, and structural properties of vaulted elements. The difference between the two is summed up in the builder's ability, or lack thereof, to move between technique and design. Examining this ability is a promising tool for the evaluation of training. Therefore, the theoretical framework used in this examination aims at illustrating a clear description of 1) the content: the transmission of knowledge through activities, 2) the context: the experience of the trainees, and 3) the relationship between the two. Two main theories will be used to examine the content and context. The first is the Sociological Theory in education developed by Basil Bernstein, and the second is the Situated Learning Theory, by Jean Lave and Etienne Wenger (Bernstein 2003: 147-77; Lave 1991; Lave and Wenger 1991).

Bernstein's sociological theory explains pedagogy in two discourses; the first is "what" we regulate as knowledge, and the second is "how" we regulate the transmission of this knowledge (Sadovnik 1991: 50). Bernstein uses "classification" for the first and "framing" for the second. The two are independent and capture the boundaries of relationships between subjects, spaces, and activities in education (Bernstein 2003: 158). Robust classification and framing produce a highly specialized and top-down curriculum, whereas weak classification and framing result in integrated bottom-up learning.

Bernstein's framework is conducive to mapping the content of learning. However, it falls short in showing how the content is translated into the learner's experience. Situated learning shifts the focus of education from content to context to explain how identities of newcomers form a "Community of Practice", defined by Wenger as "groups of people who share a concern or a passion for something they do and
Figure 1. Guastavino: workers are building a dome in the Capitol of Minnesota. (Guastavino Fireproof Construction Company architectural records, 1866-1985, Avery Architectural \& Fine Arts Library, Columbia University)

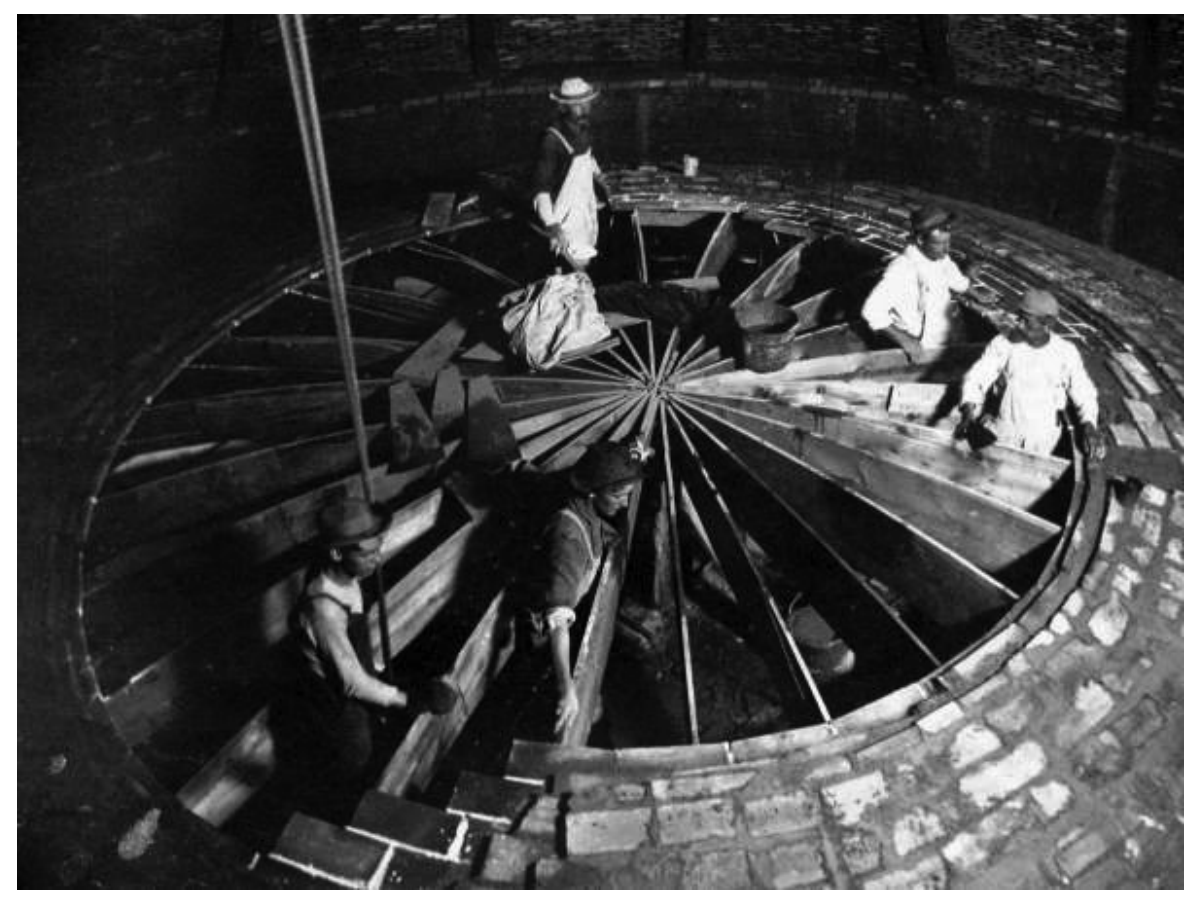


Table 1. Theoretical framework: Content and context list for analysis

\begin{tabular}{|c|c|c|}
\hline \multicolumn{3}{|l|}{ Currículum } \\
\hline \multirow[t]{2}{*}{ Classification } & Strong $(+)$ & $\begin{array}{l}\text { Separated task and activities } \\
\text { Separated theory and practice } \\
\text { Strict selection of specialisation }\end{array}$ \\
\hline & Weak (-) & $\begin{array}{l}\text { Integrated tasks in activities } \\
\text { Integrated theory and practice } \\
\text { Loose selection of specialisation }\end{array}$ \\
\hline \multirow[t]{2}{*}{ Framing } & Strong $(+)$ & $\begin{array}{l}\text { Included input from other } \\
\text { specialisations } \\
\text { Strict sequencing and pacing } \\
\text { Firm evaluation criteria }\end{array}$ \\
\hline & Weak (-) & $\begin{array}{l}\text { Excluded input from other } \\
\text { specialisations } \\
\text { Easy sequencing and pacing } \\
\text { Organic evaluation criteria }\end{array}$ \\
\hline \multicolumn{3}{|l|}{ Context } \\
\hline \multirow[t]{2}{*}{ Practice } & Profession $(+)$ & $\begin{array}{l}\text { Future market estimation } \\
\text { Alternatives materials in the local } \\
\text { market } \\
\text { Starting own business }\end{array}$ \\
\hline & Work relief (-) & $\begin{array}{l}\text { Cash for work } \\
\text { Focus on project's material only } \\
\text { Preparation for similar jobs }\end{array}$ \\
\hline \multirow[t]{2}{*}{ Community } & $\begin{array}{l}\text { Self-structured } \\
(+)\end{array}$ & $\begin{array}{l}\text { Internal organisation } \\
\text { Extended decision making } \\
\text { Skill for the future }\end{array}$ \\
\hline & Cultivated (-) & $\begin{array}{l}\text { External organisation } \\
\text { Limited decision making } \\
\text { Assignment to accomplish }\end{array}$ \\
\hline \multirow[t]{2}{*}{ Domain } & Design $(+)$ & $\begin{array}{l}\text { Placing the tile } \\
\text { Curvature estimation } \\
\text { Typologies of vaults }\end{array}$ \\
\hline & Technique (-) & $\begin{array}{l}\text { Plaster setting time } \\
\text { Clean construction } \\
\text { Speed }\end{array}$ \\
\hline
\end{tabular}

learn how to do it better as they interact regularly"(Wenger 2011: 1). The three pillars of a "Community of Practice" are the domain, community, and practice. The domain is the learned technique (thin-tile vaulting). Community is the group of trainees, and practice is the learning experience on a personal and collective level. The combination of the two notions constitutes a framework that comprises: 1) "content" and "context" criteria (Table 1 and 2) a plot to explain how the two evolve in training (Fig. 2 and Fig. 3 ).

\section{Methodological framework: Making}

At its core, this is an ethnographic study on education that is based on observation and interviews supplemented with questionnaires to observe, interact, and analyze. However, the methodology also incorporates non-textual
Table 2. Methodological framework: Observations and techniques

\begin{tabular}{|c|c|c|c|c|}
\hline $\begin{array}{l}\text { Type of } \\
\text { Observation }\end{array}$ & Technique & $\begin{array}{l}\text { During } \\
\text { training }\end{array}$ & $\begin{array}{l}\text { Outside } \\
\text { training }\end{array}$ & Offsite \\
\hline \multirow[t]{2}{*}{$\begin{array}{l}\text { Textural } \\
\text { Observation }\end{array}$} & $\begin{array}{l}\text { Notes from } \\
\text { Observations }\end{array}$ & $\mathrm{X}$ & $\mathrm{X}$ & - \\
\hline & Interviews & - & $\mathrm{X}$ & - \\
\hline \multirow{2}{*}{$\begin{array}{l}\text { Visual } \\
\text { Observation }\end{array}$} & Mapping & $\mathrm{X}$ & - & $\mathrm{X}$ \\
\hline & $\begin{array}{l}\text { Sketching with } \\
\text { builders }\end{array}$ & - & $\mathrm{X}$ & $\mathrm{X}$ \\
\hline \multirow[t]{2}{*}{$\begin{array}{l}\text { Tacit } \\
\text { Observation }\end{array}$} & $\begin{array}{l}\text { Visual } \\
\text { observation of } \\
\text { the vaults }\end{array}$ & $\mathrm{X}$ & $\mathrm{X}$ & - \\
\hline & $\begin{array}{l}\text { Building with } \\
\text { builders }\end{array}$ & - & $\mathrm{X}$ & - \\
\hline
\end{tabular}

Figure 2. Coding learning discourses by classification and framing, adopted from Basil Bernstien 2003: Context of training in terms of domain, practice, and community

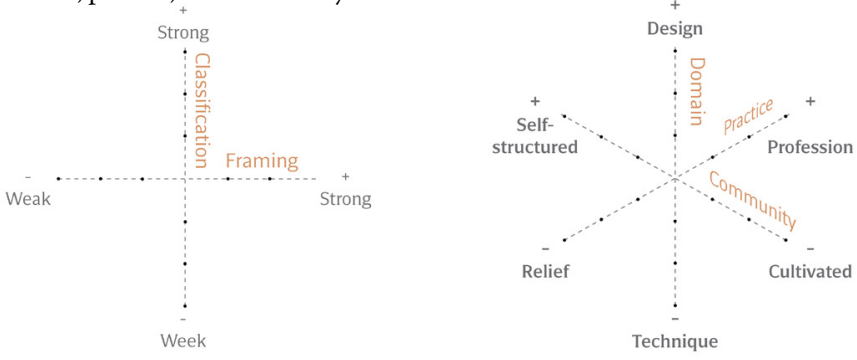

Figure 3. Context and modes of training: Left: top-down training for tasks. Right: Bottom-up training for values
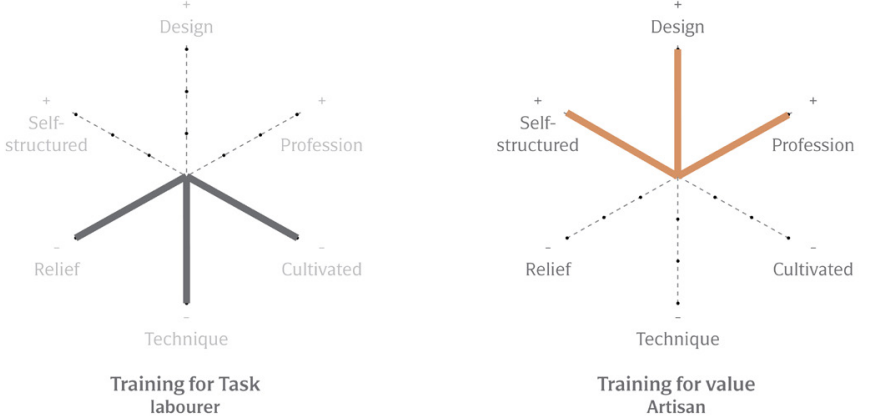

tools for the observation and exploration of the training. Increasingly common in ethnographic studies, the tools include sketching, drawing, mapping, and making which are clustered in two categories (Pink 2007). The first comprises collective activities, represented in the codrawing, co-mapping, and co-making with participants, which led to profound the discussions using line-work in addition to word-work (Fig. 4) ("Drawn to See: Drawing as an Ethnographic Method - Teaching Culture” n.d.). The second is reflective drawing and mapping, also called "concentrated seeing", that interlaces drawing with writing for analysis (Heath, Chapman, and Sketchers 2018). Reflective mapping was used to describe the spatial articulation of the training (Fig. 5). Table 2 summarizes the techniques and observational tools in the research. A map of all sketching solutions examined with the participants is shown in Fig. 6. 

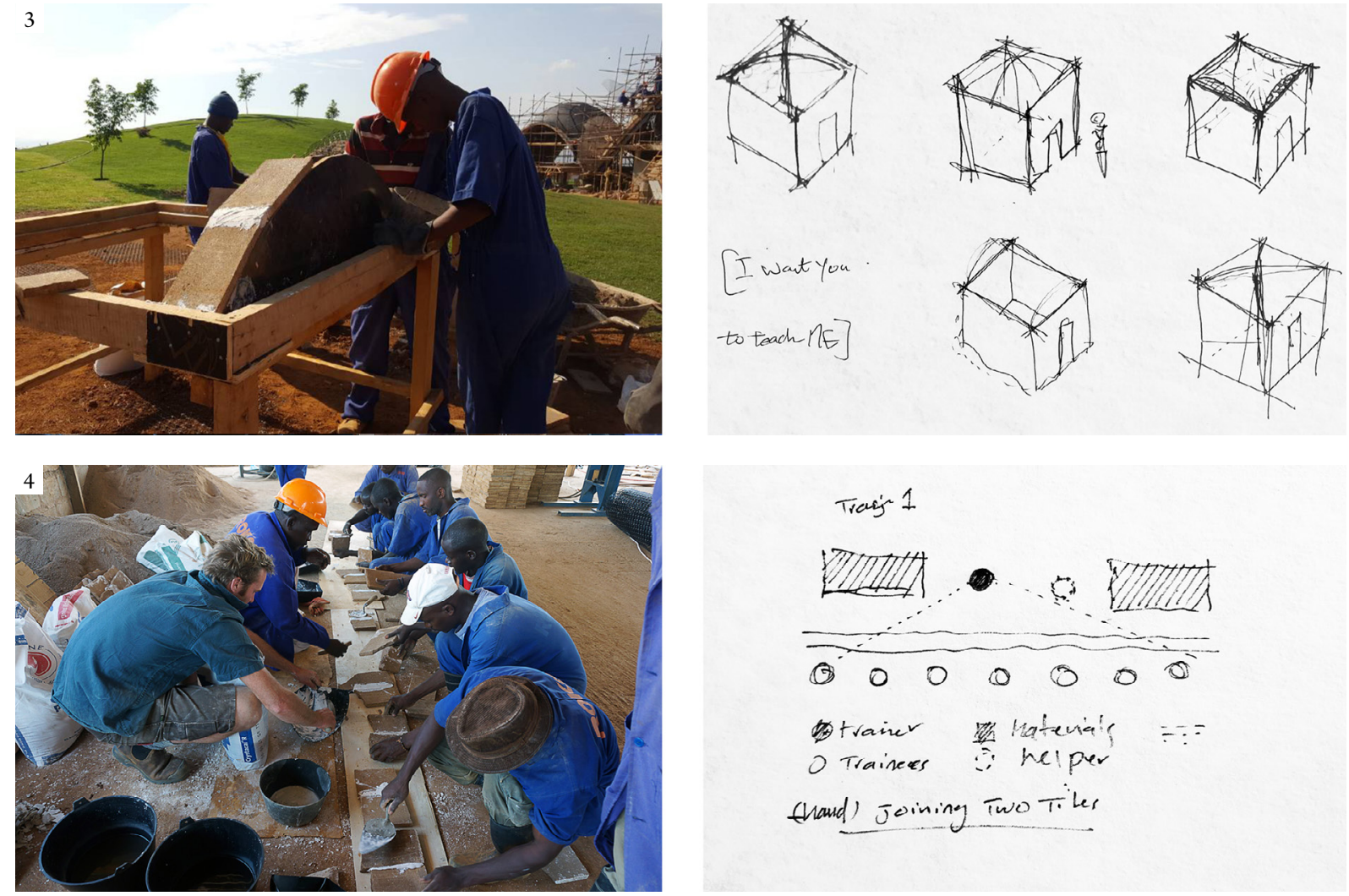

Figure 4. Making and drawing with builders, Rwanda

Figure 5. Mapping training space, Rwanda

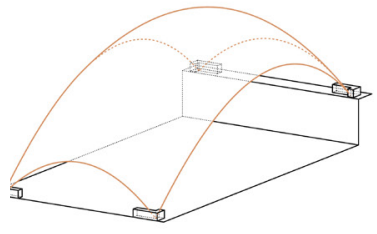

Rwanda, Cricket Stadium
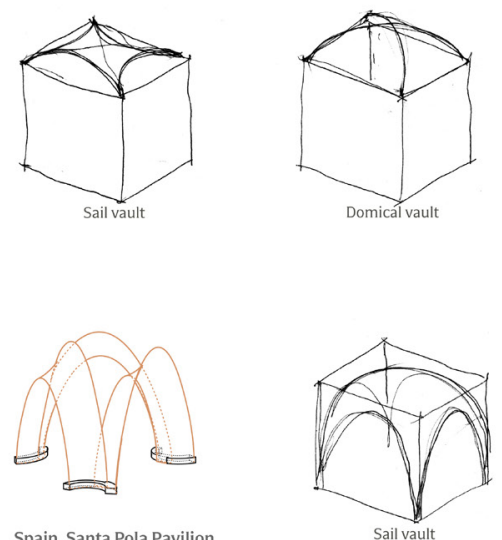

Spain, Santa Pola Pavilion

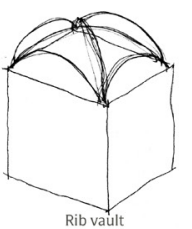

Figure 6. Sketching vaulting solution with builders

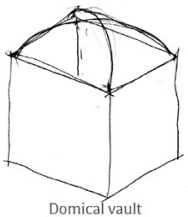

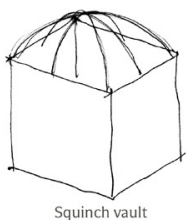
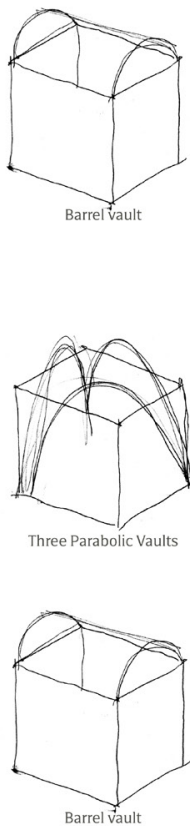

\section{First case study: Rwanda Cricket Stadium}

The Rwanda Cricket Stadium is a three-vaults pavilion located on the outskirts of Kigali (Fig. 7 and 8). Designed by Light Earth Designs (LED), it houses players' facilities and a performance space. According to Light Earth Designs, the vaults were inspired by the hilly landscape of Rwanda and the geometry of a bouncing ball. The vaults were built by local labor using stabilized earth tiles, covered with stone but left exposed on the inside.

The site's soil was used to fabricate the stabilized airdried earth tiles. A geogrid reinforcement for seismic stabilization was also used (Ramage et al. 2019). Workers were trained to produce the tiles and build the vaults. For the construction of the vaults, the one-week training program was led by James Bellamy and followed by the full-scale construction. The training for both the tile production and the vaulting took place among the workers of the contracted construction company, ROKO. The company selected 20 expert bricklayers and builders for the training.

\section{Training Description}

The workshop activities were not many, but with multiple iterations. After a general introduction, trainees were instructed to join two tiles with plaster, bringing to their attention the challenging behavior of the fast-setting mortar to avoid wasting it (Fig. 9). The second challenge was contrasting the vaulted geometry to the common 
construction of brick walls. According to James Bellamy, "good brick wall builders are not necessarily good vault makers". Therefore, joining tiles at an angle was a core topic of the workshop right from the outset. These two challenges converged into an activity of building a small catenary arch with multiple layers (Fig. 10).

After the workshop, they worked more directly but carefully on the full-scale vaults. Construction started on the full-shuttering edge arches, which allowed a transitional period between the training on small scale elements and the 7-meter span vault (Fig. 11). This transitional work proved very beneficial to gain confidence before moving on to the vault's web. Following the vault's guide work, six groups made of a vault maker and a plaster mixer were placed to start the construction, which was orchestrated by the trainer to insure in tandem and precise work that complies to the vault's geometry. The full-scale building was also a discrete and organic evaluation process. Builders who felt less comfortable with the vaulting were assigned to mix plaster and vice versa. This process resulted in groups of vault makers, plaster mixers, other layers and geogrid builders.

Figure 7. Rwanda Cricket Stadium, Kigali, Rwanda, Light Earth Design, 2019

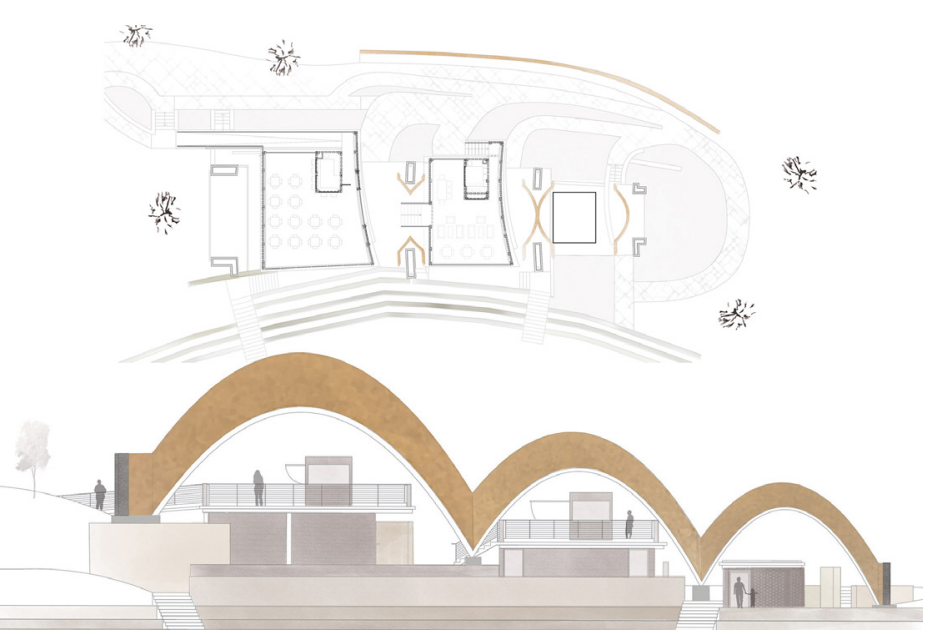

Figure 8. Rwanda Cricket Stadium, interiors, Light Earth Design, 2019

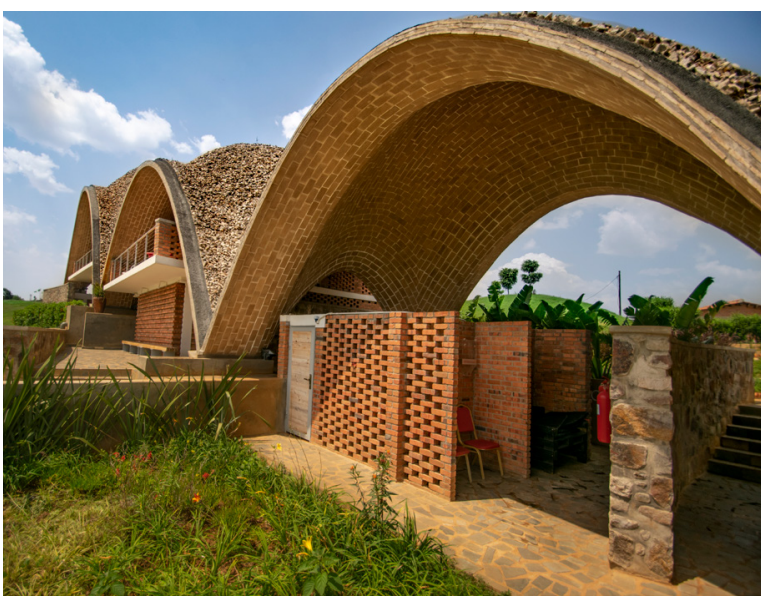

By the time the trainer left the project during the construction of the second vault, the training dynamics had changed completely from being entirely reliant on the trainer's decisions to form an autonomous system of builders. A chief builder supervised the remaining building with online coordination and reporting to James, the trainer. At this point, vaults had ceased to be uncompromisable structures.

\section{Training Content: Classification and Framing}

Strong classification flagged the training in Rwanda, with a clear curricular structure and a substantial focus on building the vaults for the project. The training had no in-depth introduction to structural design approaches. Instead, all training activities had a clear objective: understanding plaster-setting time, and cutting and positioning the tiles. Similarly, the workshop started with a strong framing. The workspace between the trainees and trainers was explicitly defined (Fig. 12). Pacing and sequencing were critical to elevate the skill of tiling. Although there were no clear evaluation criteria, skilled laborers were noted throughout the process and later chosen for the next tasks.
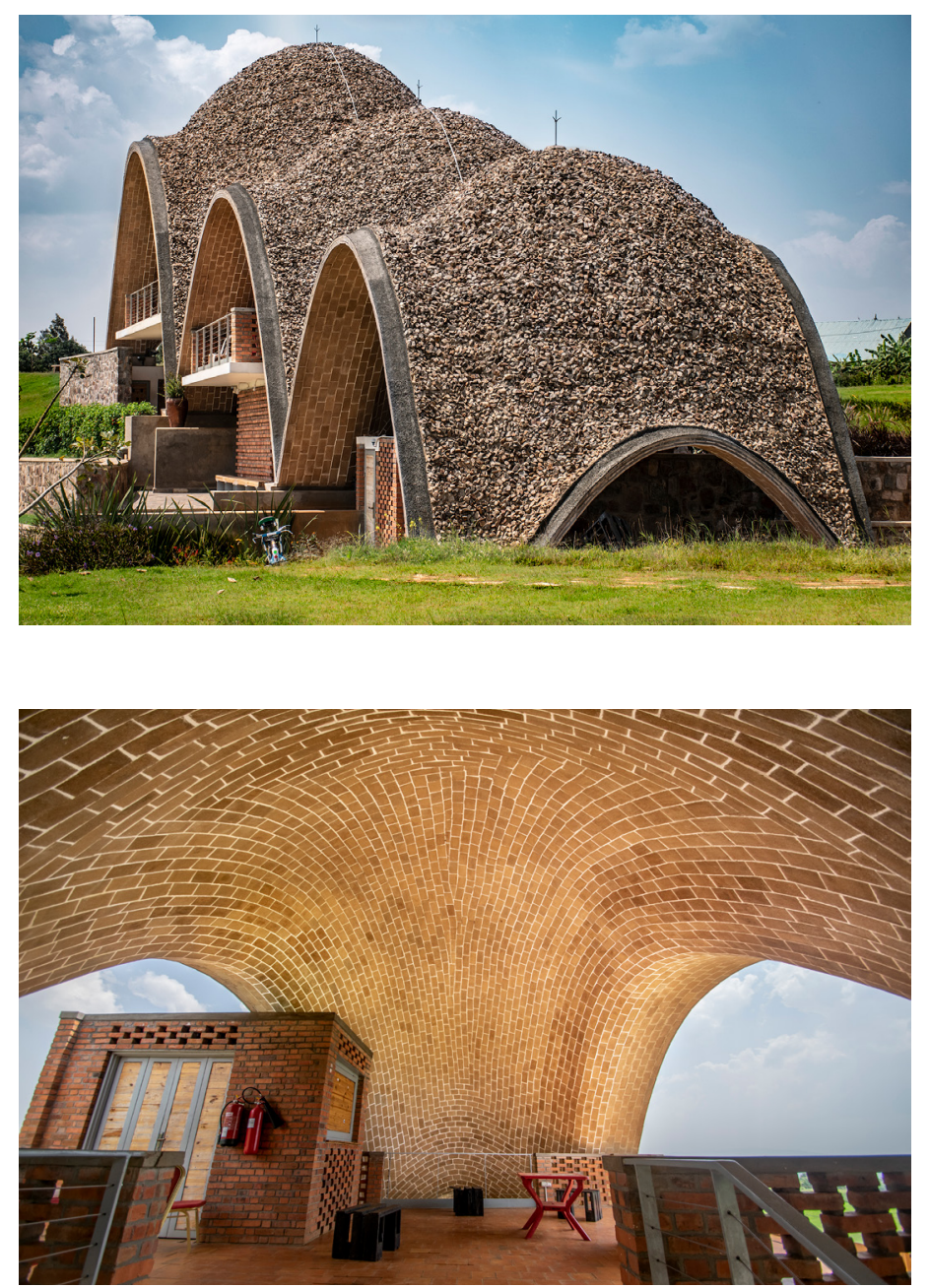

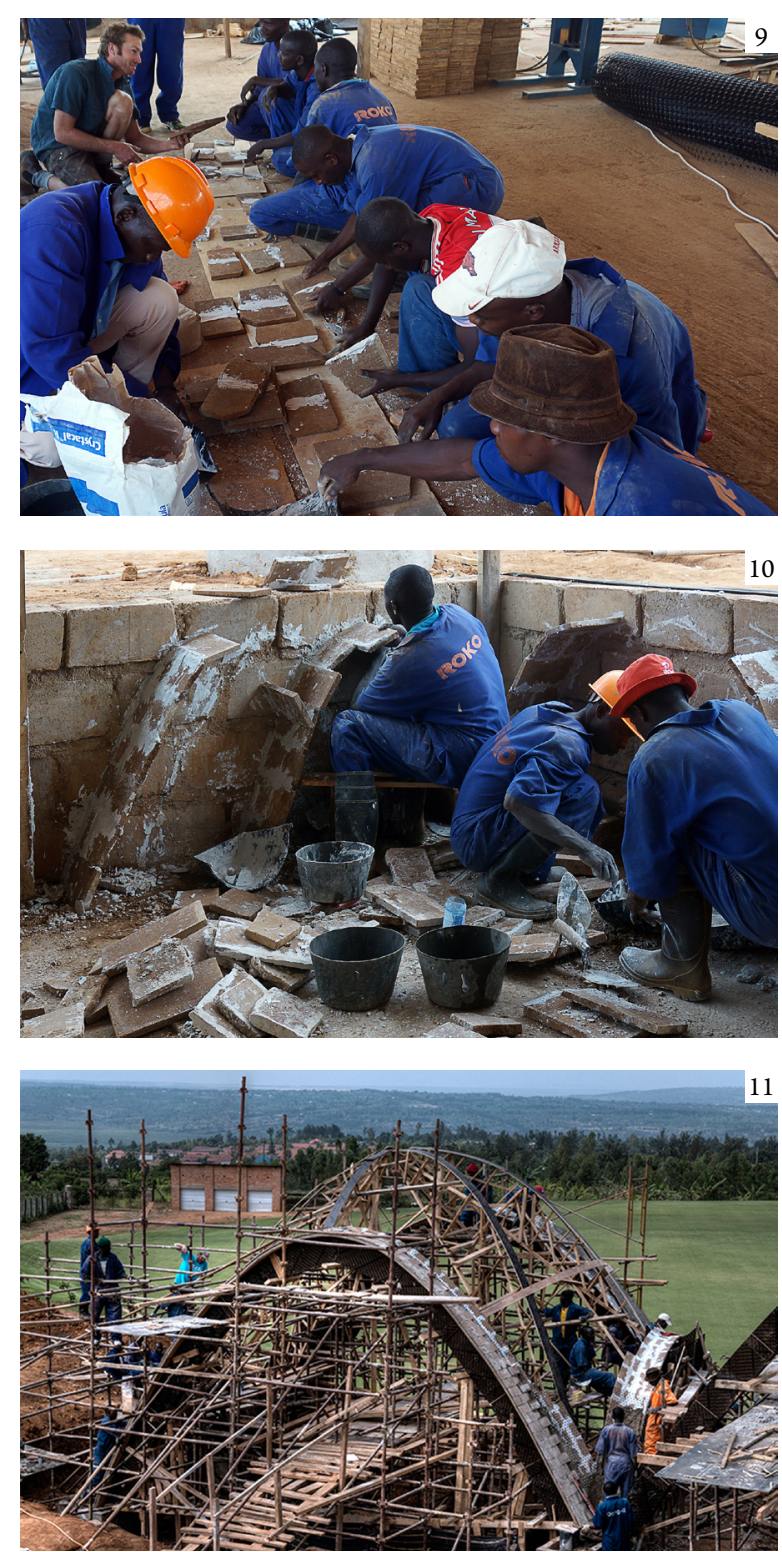

Figure 9. Rwanda Cricket Stadium training: joining two tiles

Figure 10. Rwanda Cricket Stadium training: building small vaults Figure 11. Rwanda Cricket Stadium building the edge arches

However, during the construction of the vaults the framing started to loosen; more areas of self-development were given to the builders. After rigorous induction, the head mason was given deadlines but without interfering in the builders' internal organization. James Bellamy started to allow for the builders' experience as "builders might know many ways of mixing and adding gypsum". What mattered was getting the overall construction rhythm and direction right. This change was noted in moving from small steps to the overall understanding of construction.

Builder 5: "Maybe the easiest way to explain this is: gypsum was hard then easy; curvature was easy then hard".

Builder 1: "The basics are simple; the overall thing is complicated".

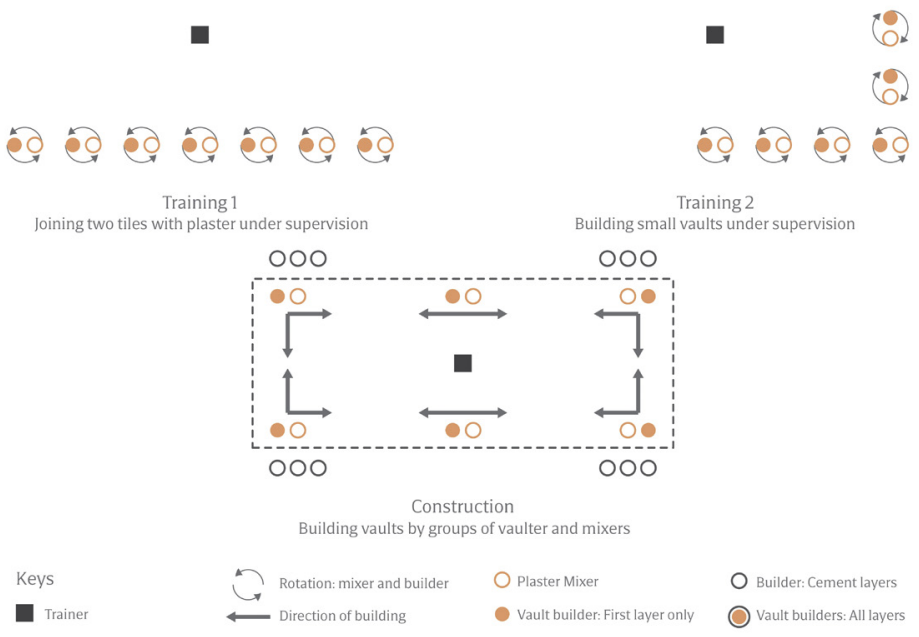

Figure 12. Spaces and organisation of training and construction of Rwanda Cricket Stadium. Both in the training and the construction, the trainer is at the centre of the space with training working around him or looking at him while demonstrating the work

\section{Training Context}

At the beginning of the workshop, before the actual construction, many expressed doubts about their ability and the technique itself. The trainees had little interest in exploring vault typologies. At the community level, a topdown hierarchy was noticed in decision-making and phasing the work. This resulted not only from site hierarchies but also from the reliance on the trainer's experience.

However, this task-oriented trend changed as the project progressed towards completion. The dynamics between the builders became fluid. Small groups of builders were formed inside the large group and distributed at the corners of the vaults. Although each group had a specific zone inside the vaults, opinions, discussions, and sometimes help were exchanged between the groups.

One of the most vivid examples of how the trained team was able to self-organize was when they trained other people.

Builder 4: "I was not part of the training; I joined the team afterwards to do plastering. But I wanted to build the vault too. I tried the technique on one side of the scaffold for some time. But then my trained friends were very confident, and they started to correct what I was doing. Little by little. Now I am part of the team; there is no difference between me and anyone who attended the initial training".

The conclusion of the project brought a "what next" to the fore. Workers were split in their answers. While many wished to build a similar project in the future, a few builders started to look for ways to make vaults in their houses. Two main obstacles hindered moving forward: the availability of the materials for tiles and geogrids and the understanding of how to design a vault for their spaces. 


\section{Discussion and Follow-up}

The context of this learning shows a positive engagement amongtheworkers, translatedintoan excellentunderstanding of the technique, but lacking a holistic approach for design and geometry, hindered by both economic and hierarchical driving forces on the construction site.

The Rwanda Cricket Stadium thin-tile training took place in an already established structure: ROKO construction company (Fig. 13). This specificity facilitated the otherwise complicated procedures of recruiting labor. That said, training within a construction company has many complexities. As part of an overwhelmingly large company, the trainees were mere recipients with little reflection on their learning. Middle management was less engaged in the construction of the vaults than builders because of unfamiliarity with the process. As a result, site and material managers reduced the project to "a complicated shape".

James was aware of the complexity of overseeing thin-tile construction, giving the "excessive components involved in building vaults". For him, the transfer is about the "confidence" that is developed during the training: "You need to find the key people to build the vault". Discussion towards the end of the workshops showed how these key people consider themselves as agile builders.

Builder 5: "A thin-tile vault builder must have an awareness of everything; he must take everything into consideration".
Builder 6: "Being good at this type of construction is not about the technical part, it is about the logic of foreseeing problems and solving them before they happen".

Workers in ROKO can build more vaults. However, this is unlikely to happen outside a construction project similar to the Rwanda Cricket Stadium. Drawing on his previous experience in Mapungubwe, in South Africa, James expressed little confidence in making thin-tile vaulting part of the common local construction practices in South Africa or Rwanda. When asked about its possible application for self-building houses in South Africa, he stated: "We tried to look at the house's design to pass on and replicate the knowledge. We taught the locals how to put roofs on their houses. They liked the idea, but it was far-fetched and, the way it is done there, would become very expensive".

The socioeconomic circumstances limit any autonomous use of thin-tile vaulting that is not part of a construction company project. Both the trainer and the design team lead were aware of these realities from a previous, similar project in Mapungubwe (Splaingard 2016). They stated clearly that any skill transfer of thin-tile vaulting was aimed at the construction of this project and similar projects that ROKO might potentially undertake in the future.

Figure 13. Positive development of training in Rwanda Cricket Stadium from tasks with strong classifications and framing (left) to values with weak framing (right): The development was noted by self-organisation and a better understanding of vault's design among builders

\begin{tabular}{|l|l|l|l|l|l|}
\hline \multicolumn{2}{|l|}{ Content } \\
$\begin{array}{l}\text { Classification } \\
\text { Strong vs. } \\
\text { Weak }\end{array}$ & Start & End & $\begin{array}{l}\text { Classification } \\
\text { Strong vs. Weak }\end{array}$ & Start & End \\
\hline $\begin{array}{l}\text { Theory/ } \\
\text { Practice }\end{array}$ & + & + & $\begin{array}{l}\text { Trainer / Trainee } \\
\text { Relationship }\end{array}$ & + & - \\
\hline $\begin{array}{l}\text { Activities/ } \\
\text { Tasks }\end{array}$ & + & + & $\begin{array}{l}\text { Sequencing } \\
\text { / Pacing / } \\
\text { Evaluation }\end{array}$ & + & - \\
\hline Specialisation & + & - & $\begin{array}{l}\text { Inside/outside } \\
\text { Knowledge }\end{array}$ & + & + \\
\hline
\end{tabular}

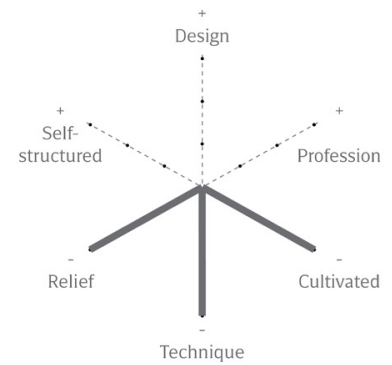

Before Trainintg

C: Very Strong

F: Very Strong

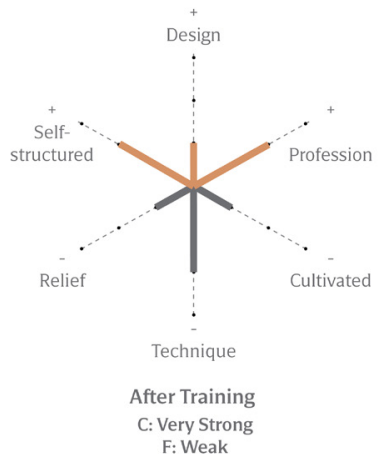

C: Very Stron

\begin{tabular}{|l|l|l|l|l|l|l|l|l|}
\hline \multicolumn{2}{|l|}{ Context } \\
\hline $\begin{array}{l}\text { Practice } \\
\text { Work relief vs. } \\
\text { profession }\end{array}$ & Start & End & $\begin{array}{l}\text { Community } \\
\text { Cultivated vs. Self- } \\
\text { structured }\end{array}$ & Start & End & $\begin{array}{l}\text { Domain } \\
\text { Technique vs. Design }\end{array}$ & Start & End \\
\hline $\begin{array}{l}\text { Market/ } \\
\text { Employment }\end{array}$ & - & - & $\begin{array}{l}\text { Organisation } \\
\text { External / Internal }\end{array}$ & - & + & $\begin{array}{l}\text { Tile placing / speed / } \\
\text { precision }\end{array}$ & - & - \\
\hline $\begin{array}{l}\text { Development/ } \\
\text { Adaptation }\end{array}$ & - & + & $\begin{array}{l}\text { Decision making } \\
\text { Extended- limited }\end{array}$ & - & + & $\begin{array}{l}\text { Curvature formwork } \\
\text { /no formwork }\end{array}$ & - & + \\
\hline $\begin{array}{l}\text { Usability /self- } \\
\text { building }\end{array}$ & - & + & $\begin{array}{l}\text { Boundaries } \\
\text { Onsite- offsite }\end{array}$ & - & - & $\begin{array}{l}\text { Geometry/ } \\
\text { typologies }\end{array}$ & - & - \\
\hline
\end{tabular}




\section{Second case study: Santa Pola Cultural Center in Spain}

An outdoor pavilion at the Center of the Arts and Culture in Santa Pola, Alicante, was designed and built as part of a vocational training program ultimately aimed at the rehabilitation of the building. The construction of the vault needed to be customized, so trainers could still participate in the building process. The design has a triangular layout with three catenary vaults at the edges. Each vault sweeps over a curved base, generating a simultaneous change in the height as it opens or closes. The result is an agglomeration of doubly-curved vaults that, while exhibiting compositional complexity, are easy to build because of their modularity (Fig. 14).

\section{Training Description}

The one-week workshop was part of an extended 9-month vocational training program for youth. The training strategy, led by Spanish master-builder Salvador Gomis, integrated design with construction and included theory sessions and discussion about vaulting during and after the construction (Fig. 15). Theory sessions were handson. Chains, strings, and small blocks were used to explain lines of thrusts in load-bearing vaulting, graphic statics and simple construction methods. This practice aimed at providing trainees with the simplest onsite method for building a vault when needed. The trainer used a chain and wooden boards to both form-find the section of the vault and to use the board as formwork when flipped (Fig. 16). The board served as a wall on which several arches were built before it was removed (Fig. 17). The twelve workshop participants worked collectively on the making and installation of the formwork. Because the group of trainees was small, the interaction with the builders in the pavilion was very vibrant, with questions and comments. In a nearby area, participants worked in teams of two to replicate the construction of the pavilion on a smaller scale (Fig. 18). The construction of the small arches was lightly supervised and students tried to apply what they were learning from the large structures with a margin for trial and error. They were also allowed to experiment with their structures.

\section{Training Content: Classification and framing}

Weak classification and framing prevailed at the training workshop in Santa Pola, as no strong boundaries were formalized between the subjects of learning. The training program did not make a clear distinction between the activities and the tasks. The pavilion construction was mainly led by the trainer, who was supportive of this approach to give participants an experimentation zone in smaller vaults. The supplementary small arch construction was entirely open to experimentation and interpretation

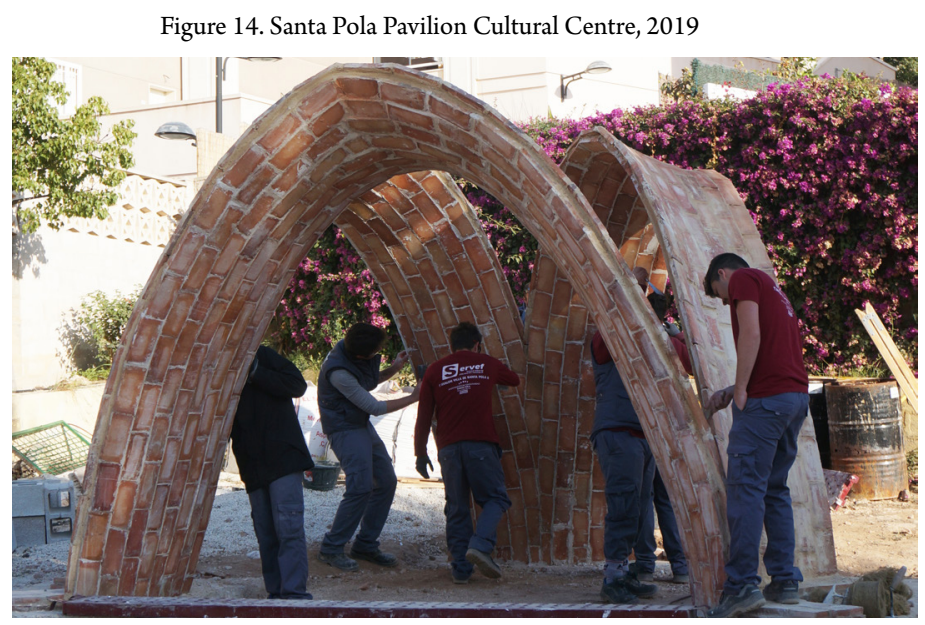

Figure 15. Santa Pola Pavilion: Details
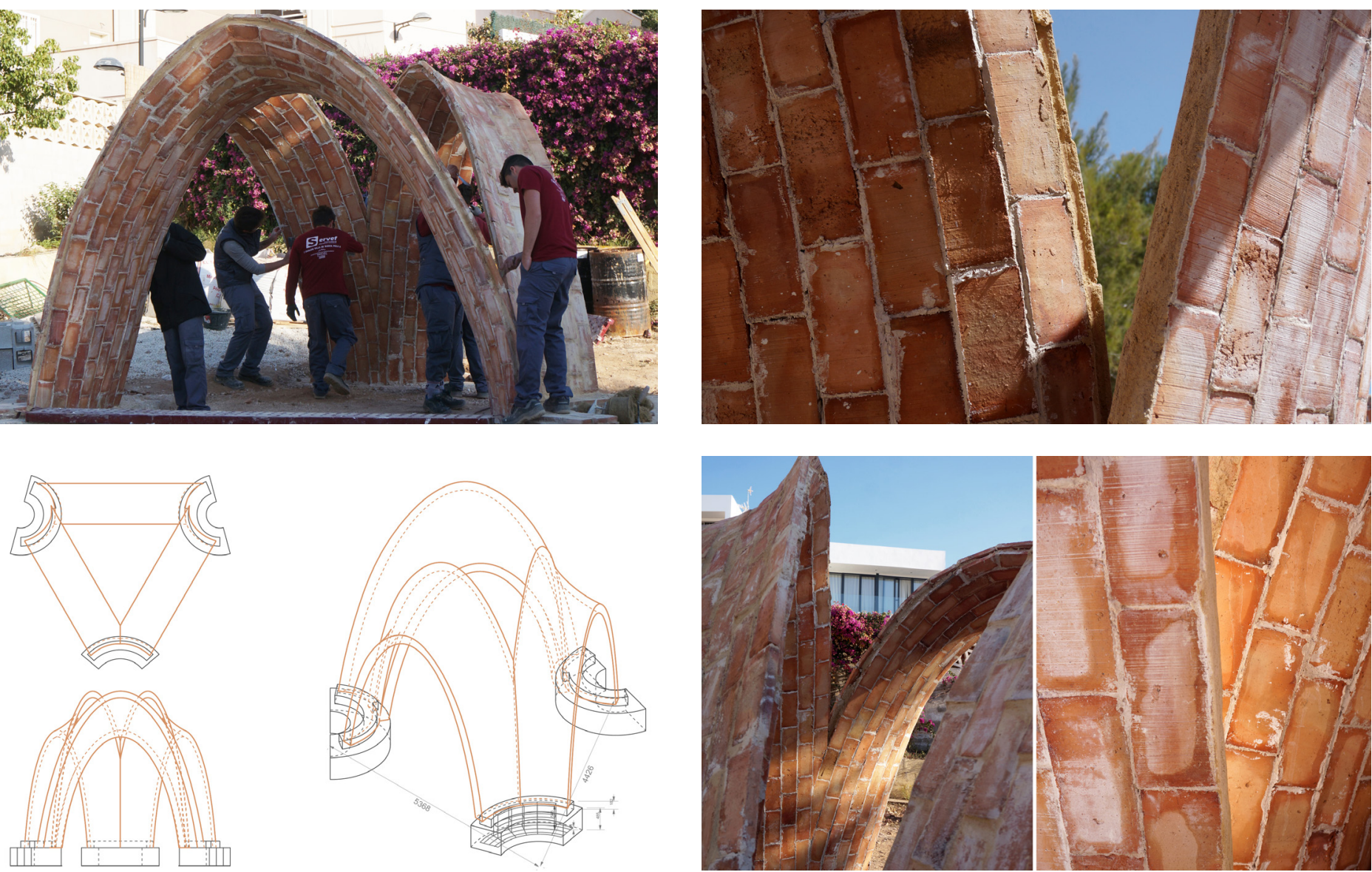
of the thin-tile building by small teams of trainees. In framing, outside knowledge and experience from previous training, such as masonry and bricklaying, were present in the discussion about the vaults. These discussions allowed for talking about more vaulting techniques and associating or contrasting them with thin-tile vaulting. Finally, in both theory and practice sessions, there were no boundaries between the trainers' and the trainees' space (Fig. 19).

Stronger framing emerged towards the conclusion of the workshop; participants were asked to finish their final arch mock-ups. Pacing became stronger; participants were given one day to finish the arches. Spatially, the workshop was split between trainers finishing the pavilion, and trainees finishing their small arches (Fig. 19). Generally, participants gave positive feedback about this change in the rhythm of the construction, stating that it gave them more confidence in what they are doing.

\section{Training Context}

Observing how participants responded to the workshop shows a shift from general discussions to the concise task of building. Classroom sessions also had an impact on the language between the trainees; students moved from

Figure 16. Pavilion training: Making the foundation and formwork of the Pavilion

Figure 17. Construction of the Pavilion

Figure 18. Training: Participants practicing on small vaults

Figure 19. Spaces and organisation of training and construction of the Pavilion in Santa Pola
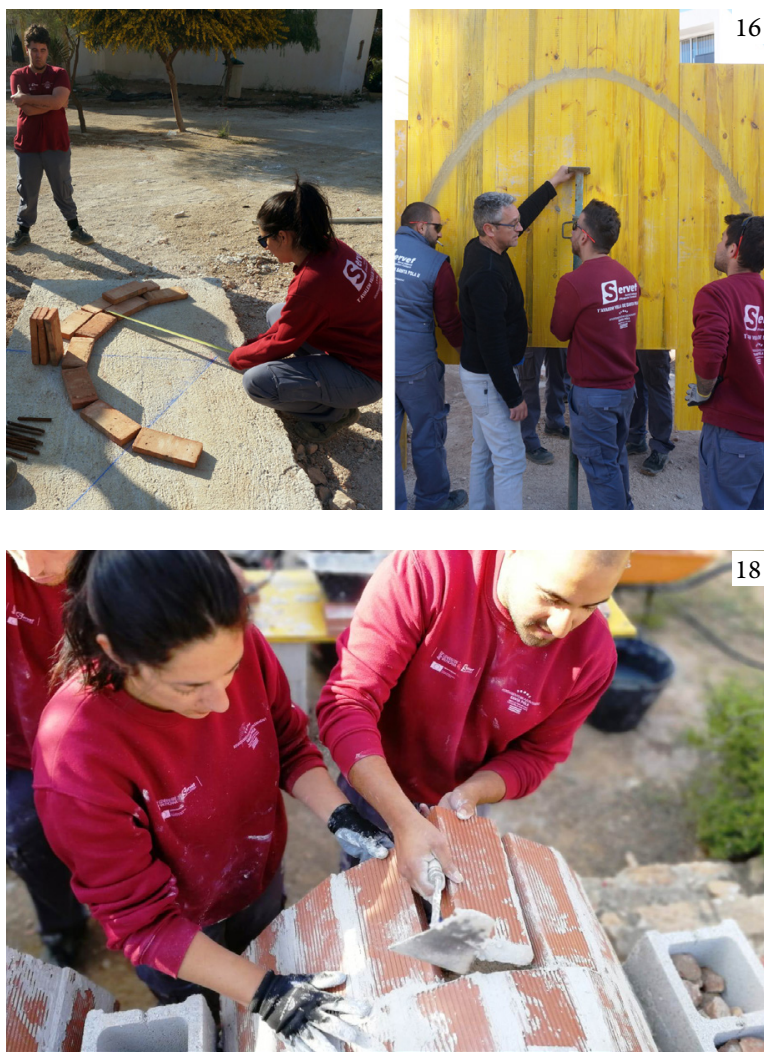

talking about strong and weak vaults to talking about lines of thrusts and vault masses. The presence of a training goal, represented by the construction of a pavilion, motivated the participants. Vault design and calculation sessions were vibrant, with many questions and projections from thintile vaulting to concrete shells. Unexpectedly, sustainability as an aspect of thin-tile vaulting was very central to the discussions. Trainees were interested in those alternatives that are "more sustainable", such as replacing cement with lime for the mortar used in the second layers.

As the workshop progressed, small groups started to form and the organization was considered a prerequisite to building a vault.

Builder 4: "Perhaps the most important thing in building vaults is cooperation and teamwork".

Builder 3: "What I liked about the workshop was the experience, both in exploring ideas and in realizing them".

When the workshop ended, the work on smaller arches showed a fast-forming, responsive and decision maker groups of two. Although the outcome of these arches was not of a high craft, the process learned from the construction of the pavilion was organically followed. The discussions on the design of the vaults helped the trainees to make their structures without intensive help from trainers. This raised confidence in the participants' work and ideas.

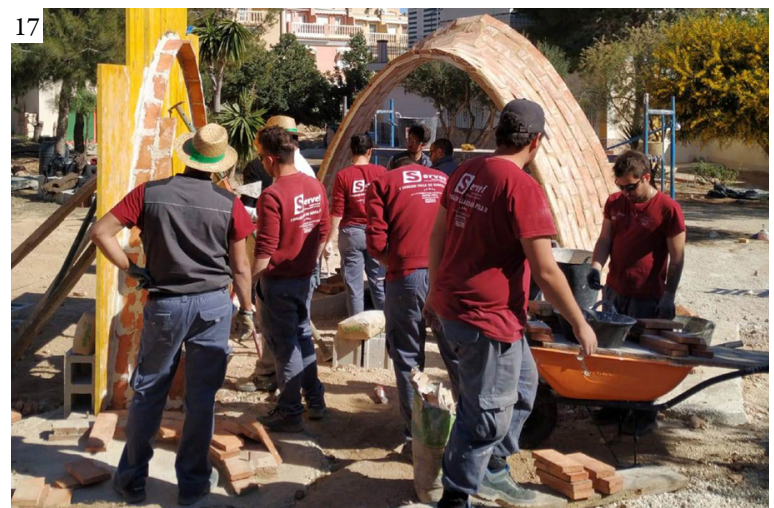

19
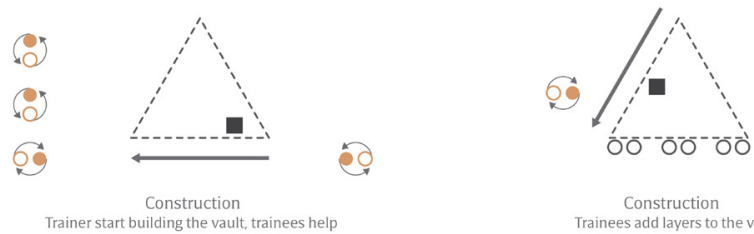
Construction
Trainees add layers to the vaut

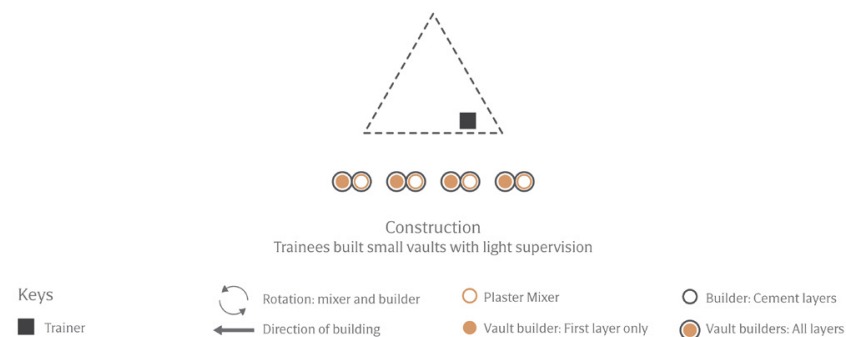


$\underline{\text { Discussion and follow-up }}$

Unlike regular craft training, the thin-tile vaulting workshop in Santa Pola goes from the general to the specific. The result was a comprehensive examination of how vaults work, which proved beneficial as the training progressed (Fig. 20). The shift from the general to the specific relinquished any divisions between subjects of learning, theory and application, trainers and trainees. The evaluation and pacing of the work were not essential during the workshop except for the last day, when participants were asked to build vaults in one day. This training system model offered an extended sense of "personal authorship" and a "zone for trial and error", which elevated the trainees' engagement with the construction. It also offered a "reference for comparison" represented by the central vault that the trainer was building, "a live art performance" as one participant phrased it. However, the weak framing at the beginning of the training allowed some to withdraw from activities; two participants preferred to only prepare materials and did not engage in any design practice.

A training program with weak classification and framing was possible on this project because of its small scale, and the active role played by the trainer in building the pavilion. At the end of the workshop, students were able to give various examples of vaulted structures. However, the construction of these vaults would require more technical training for well-executed structures, either by practicing on many small projects or apprenticing as a thin-tile vault maker, both of which are possible in Spain.

\section{Conclusion}

The research examines two training programs in two thintile vaulted projects: the Rwanda Cricket Stadium and the Event Pavilion at the Santa Pola Cultural Center. The two projects examined represent two complementary training modes: practiced training and expanded training.

In practiced training, the focus is on applications, which includes controlling the plaster setting time, the position of the tiles, and speed. It has strong classification and framing with strictly dictated tasks, evident in the construction of the Rwanda Cricket Stadium. In this training, vaulting is unlikely to be extended outside the intended project, due to the limited knowledge of geometry and vault design. In the expanded training, the focus is on the design of the vaults, the substructure, and the selection of appropriate materials. This training constructs a community of practice by preparing key persons to coordinate the project with "confidence", an "agile" understanding of the process, and an eye for estimating the vault's "curvatures". This training was evident in Santa Pola's pavilion. Builders in this training can identify a vault, but they will need more focused selfpractice to improve the detailing and speed of building.

It should be noted that the two training strategies are complementary. Expanded training can serve as an introductory activity to practiced training, or it can also be a follow-up activity. In Rwanda, after the construction of the project it took only one day to discuss vault geometries and build them by loosening classification and framing. The

Figure 20. The positive development of training in Santa Pola: From "task" training to "value" training, developing a weak framing into a stronger one. The training starts with reflections and explorations and ends with applications of skills

\begin{tabular}{|l|l|l|l|l|l|}
\hline Content & Start & End & $\begin{array}{l}\text { Classification } \\
\text { Strong vs. Weak } \\
\begin{array}{l}\text { Strong vs. } \\
\text { Weak }\end{array}\end{array}$ & Start & End \\
\hline $\begin{array}{l}\text { Theory/ } \\
\text { Practice }\end{array}$ & - & + & $\begin{array}{l}\text { Trainer / Trainee } \\
\text { Relationship }\end{array}$ & - & + \\
\hline $\begin{array}{l}\text { Activities/ } \\
\text { Tasks }\end{array}$ & - & + & $\begin{array}{l}\text { Sequencing } \\
\text { / Pacing / } \\
\text { Evaluation }\end{array}$ & - & + \\
\hline Specialisation & - & + & $\begin{array}{l}\text { Inside/outside } \\
\text { Knowledge }\end{array}$ & - & - \\
\hline
\end{tabular}
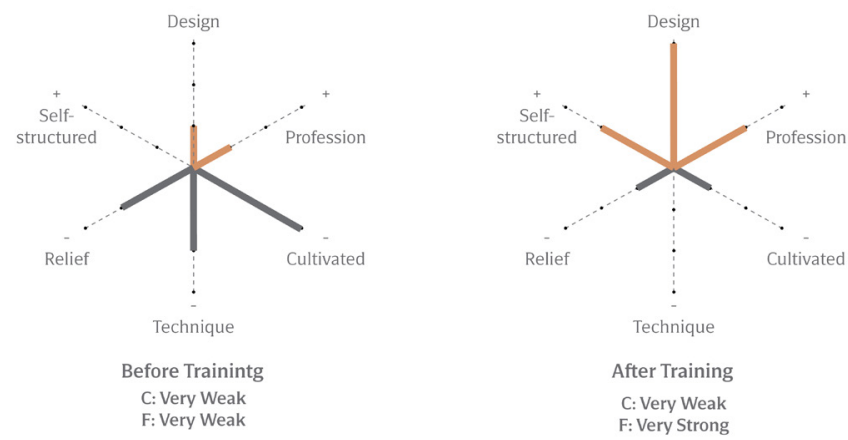

\begin{tabular}{|c|c|c|c|c|c|c|c|c|}
\hline \multicolumn{9}{|l|}{ Context } \\
\hline $\begin{array}{l}\text { Practice } \\
\text { Work relief vs. } \\
\text { profession }\end{array}$ & Start & End & $\begin{array}{l}\text { Community } \\
\text { Cultivated vs. Self- } \\
\text { structured }\end{array}$ & Start & End & $\begin{array}{l}\text { Domain } \\
\text { Technique vs. Design }\end{array}$ & Start & End \\
\hline $\begin{array}{l}\text { Market/ } \\
\text { Employment }\end{array}$ & + & + & $\begin{array}{l}\text { Organisation } \\
\text { External / Internal }\end{array}$ & - & - & $\begin{array}{l}\text { Tile placing / speed / } \\
\text { precision }\end{array}$ & - & + \\
\hline $\begin{array}{l}\text { Development/ } \\
\text { Adaptation }\end{array}$ & - & - & $\begin{array}{l}\text { Decision making } \\
\text { Extended-limited }\end{array}$ & - & + & $\begin{array}{l}\text { Curvature formwork / } \\
\text { no formwork }\end{array}$ & - & + \\
\hline $\begin{array}{l}\text { Usability /self- } \\
\text { building }\end{array}$ & - & + & $\begin{array}{l}\text { Boundaries } \\
\text { Onsite- offsite }\end{array}$ & - & + & Geometry/typologies & + & + \\
\hline
\end{tabular}


opposite happened in Spain, where integrated curriculum became strict towards the end of the construction (Fig. 21).

Choosing and constructing the two models is related to the reading of the project's context. One of the crucial elements of context is the "institution" of the training in which the dynamics of power and control affect aspirations and realities. Working with these dynamics contributes to establishing a community of training, a precondition for a successful and sustained participation of builders in the construction. Another crucial element is the phasing of training within the scale and complexity of the vaults. In Rwanda, the construction of the edge arches which were built with full formwork proved very useful. Finally, introducing thin-tile vaulting in new regions must take into consideration the diverse "components" of the technique: materials or material alternatives, production systems, and the informal and formal construction market. While essential to procurement and resourcing, these considerations give an idea of what a builder can (or cannot) do with this skill after the construction of the project. From discussion with trainees in the examined workshop, three industries were mapped and considered essential to the building trades in general: artisanal work, construction, and restoration. Therefore, craft training should be situated at the intersection between those three industries (Fig. 22).

However, learning a craft within these sectors requires time. The critical question in today's training of craft lies somewhere between the two conventional modes of tooshort training and too-long training. The two training

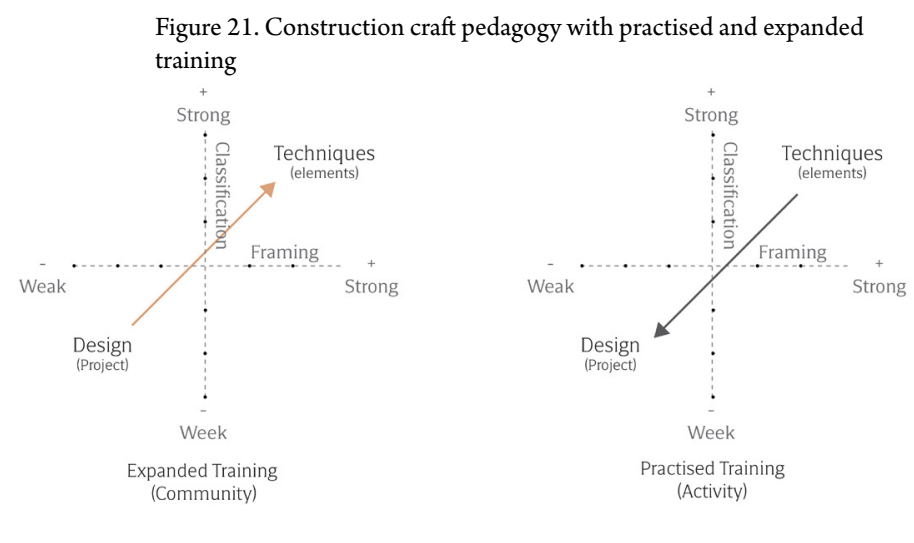

Figure 22. Training model within existing business models

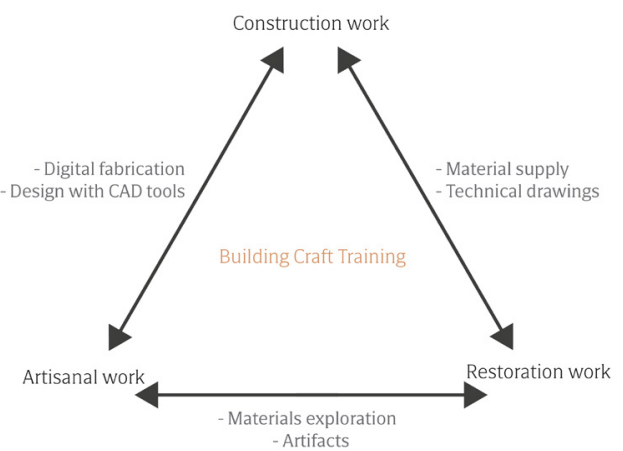

models (practiced and principled) that emerge from an examination of the training programs are useful in answering the question.

Instead of approaching training by length, it can be described by its nature. Community as an "expanded training" can be observed in the construction of the pavilion in Santa Pola. Activities in "practiced learning" that involve strict stages of learning are obvious in the case of Rwanda, and can serve to magnify the role and impact of small tasks within the overall project. In other words, the goals of practiced training can be achieved through activities, and the goals in principled training can be achieved through a community of artisans, apprentices and architects. Training of craft can be seen as the ability to move between the activities and communities of this craft.

The proposed training model is also relevant to the design education within schools of architecture. It shows that a holistic and general approach to learning a construction craft leads to specific, tacit knowledge with short but rigorous iterations of sessions. When there are no small tasks, design can be approached by paying attention to reporting, reflecting, and reiterating what seems very vocational in a design studio, such as wood carving, cutting or concrete casting. The dialogue between the tasks and the project can also be projected onto an entire design curriculum at schools of architecture.

This leads to the second contribution of the proposed craft learning model to design learning. Building for the community is central in design-build education, but building with the community is less tackled, i.e., the analysis and engagement of local methods of building. If design-build pedagogy in architecture strives to at least partially replace the often lost master-apprentice, looking at recent experiences in the teaching of traditional craft is a must. The design-build project should capitalize not only on introducing a new way of making to the site, but also on

Figure 23 Training model in Construction Craft
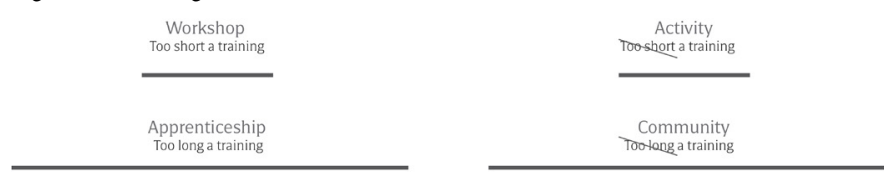

A

B

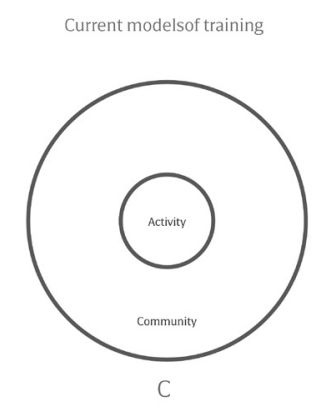

Practiced and Expanded Training zones

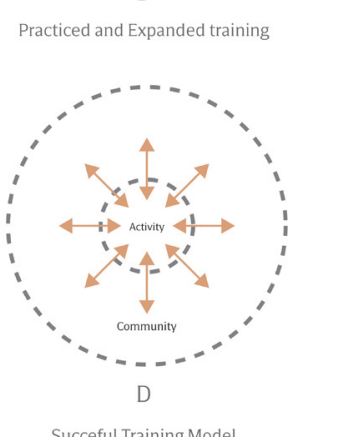


learning a new way of making from the site-the two are usually interconnected. Under the current environmental emergency, one of the most pressing skills to learn is how to create a dialogue with culture as a site. Thin-tile vaulting, as a craft, has proved to be a capable medium for this dialogue. Similar mediums should be investigated and employed for broader research on teaching craft in the era of fastfabrication methods and specialized education strategies.

\section{Acknowledgement}

The authors would like to thank the thin-tile vaulting trainers, Salvador Gomis and James Bellamy. This article is part of $\mathrm{Al}$ Asali's doctoral thesis on craft-inclusive thintile vaulting construction funded by the Said FoundationCambridge Trust Grant. The fieldwork in Rwanda was supported by the Boak Fund from Clare Hall.

\section{Bibliography | Bibliografía | Bibliografia}

Bassegoda Musté, Buenaventura; and Bassegoda Nonell, Juan. 1947. La Bóveda Catalana. Zaragoza: Institución Fernando el Católico, Diputación de Zaragoza.

Bernstein, Basil B. 2003. Class, Codes and Control: Theoretical Studies towards a Sociology of Language. London: Psychology Press.

Churtichaga, José María (ed.). 2001. Villanueva de la Cañada, historia de una reconstrucción. Villanueva de la Cañada: Concejalía de Cultura.

Collins, George R. 1968. The Transfer of Thin Masonry Vaulting from Spain to America. Journal of the Society of Architectural Historians / Society of Architectural Historians: 176-201.

Causey, Andrew. 2016. Drawn to See: Drawing as an Ethnographic Method | Teaching Culture, http://www.utpteachingculture.com/drawn-to-seedrawing-as-an-ethnographic-method/ (consulted on 06/04/2020).

Fuentes, Paula; and Huerta, Santiago. 2014. Bóvedas sin cimbra: La construcción tabicada. Memoria académica del taller experimental de Historia de la Construcción del curso 2013/2014. Madrid: Instituto Juan de Herrera. https://www.academia.edu/40194133/B\%C3\%B3vedas_ sin_cimbra_La_construcci\%C3\%B3n_tabicada_Memoria acad $\%$ C3\% $\%$ Amica_del_taller_experimental_de_Historia_de la_Construcci\%C3\%B3n_del_curso_2013_2014 (consulted on 08/04/2020).

García-Gutiérrez Mosteiro, Javier. 1996. El sistema de bóvedas tabicadas en Madrid: de Juan Bautista Lázaro (1849-1919) a Luis Moya (1904-1990). Actas del Primer Congreso Nacional de Historia de la Construcción: 231-42. Madrid: Centro de Estudios y Experimentación de Obras Públicas, CEDEX.

Heath, Sue; Chapman, Lynne; and The Morgan Centre Sketchers. 2018. Observational Sketching as Method. International Journal of Social Research Methodology, vol. 21, 6: 713-728, https://www.tandfonline. com/doi/abs/10.1080/13645579.2018.1484990 (consulted on 10/04/2020).

Homo Faber. 2020. Rehabilitación de Edificios y Cursos de Oficios.http:// homofabercursos.com/ (consulted on 07/04/2020).

Lave, Jean. 1991. Situating Learning in Communities of Practice. In Resnick, Lauren B.; Levine, John M.; and Teasley, Stephanie D. (eds.). Perspectives on Socially Shared Cognition, 63-82. Washington, D.C.: American Psychological Association.
Lave, Jean; and Wenger, Etienne. 1991. Situated Learning: Legitimate Peripheral Participation. Cambridge: Cambridge University Press.

Méndez Rodríguez, Francisco Javier; and González Fueyo, José. 2009. La Construcción de la Universidad Laboral de Zamora. Actas del VI Congreso Nacional de Historia de la Construcción: 1179-88. Valencia: Escuela Politécnica de Valencia e Instituto Juan de Herrera.

Ochsendorf, John. 2010. Guastavino Vaulting: The Art of Structural Tile. New York: Princeton Architectural Press.

Origens Escola Taller de Bioconstrucció. 2020. https://escolaorigens. com/ (consulted on 16/04/2020).

Pink, Sarah. 2007. Doing Visual Ethnography. London: SAGE Publications, https://doi.org/10.4135/9780857025029.

Ramage, Michael H. 2007. Guastavino's Vault Construction Revisited. Construction History, 22: 47-60.

Ramage, Michael; Hall, Timothy J.; Gatóo, Ana; and Al Asali, M. Wesam. 2019. Rwanda Cricket Stadium: Seismically Stabilised Tile Vaults. Structures, 18: 2-9, https://doi.org/10.1016/j.istruc.2019.02.004.

Sadovnik, Alan R. 1991. Basil Bernstein's Theory of Pedagogic Practice: A Structuralist Approach. Sociology of Education, vol. 64, 1: 48-63.

Splaingard, Daniel Robert. 2016. The Effects of Architectural Design on South African Expanded Public Works Programme Goals. Emerging Trends in Construction Organisational Practice s and Project Management Knowledge Area: 172-81. Cape Town: Openbooks.

Workshop: VIII Taller de Bóvedas Tabicadas - MUPAAC. 2020, http:// www3.uah.es/mupaac/viii-taller-de-bovedas-tabicadas/ (consulted 10/04/2020).

Wenger, Etienne. 2011. Communities of Practice: A Brief Introduction, https://www.researchgate.net/publication/235413087 Communities_of_Practice_A_Brief_Introduction (consulted on 08/04/2020)

\section{Biography $\mid$ Biografía | Biografia}

\section{Wesam Al Asali}

$\mathrm{He}$ is an Architect and a doctoral researcher at the Centre for Natural Material Innovation at the University of Cambridge. His work investigates how tile-vaulting responds to different forms of scarcities. Through design, making, and case studies in Cuba, Spain, and Syria, he examines how technology, manufacturing, and craft training in tile-vaulting can be facilitators of locally resourced construction during economic hardship, emergency, and post-war reconstruction. Wesam leads IW-lab in Damascus, Syria, which investigates the manifestation of crafts in informal architecture and construction. Wesam is a co-founder of CERCAA, a training center advocating and developing programs for construction and craft in the context of environmental emergencies.

\section{Michael H. Ramage}

He leads the Centre for Natural Material Innovation at Cambridge University, and is an architectural engineer and Senior Lecturer in the Department of Architecture, a fellow of the Sidney Sussex College, and a founding partner of Light Earth Designs. He studied architecture at MIT, and worked for Conzett Bronzini Gartmann in Switzerland prior to teaching at Cambridge. His current research is focused on developing lowenergy structural materials and systems in masonry, better housing in the developing world and improved engineered timber and bamboo through natural material innovation. He teaches, researches and designs buildings, and receives research funding from the Leverhulme Trust, the Engineering and Physical Sciences Research Council, the Royal Society, the British Academy, and industry. 